\title{
Effects of Plant Oils and Minerals for the Inhibition of Lipase Activity of Staphylococcus aureus Isolated from Fermented Pork Meat
}

\author{
Sang-Buem Cho ${ }^{1,2}$, Woo-Kyung Chang ${ }^{1}$, Yun-Jung Kim¹, Hyung-In Moon ${ }^{1,2}$, \\ Jong-Won $\mathrm{Joo}^{3}$, In-Soo $\mathrm{Choi}^{4}$, Kun-Ho Seo ${ }^{4}$, and Soo-Ki Kim ${ }^{1,2 *}$ \\ ${ }^{1}$ Department of Animal Science and Environment, Konkuk University, Seoul 143-701, Korea \\ ${ }^{2}$ Animal Resources and Research Center, Konkuk University, Seoul 143-701, Korea \\ ${ }^{3}$ Department of Companion Animal Science, Joongbu University, Chungnam 312-702, Korea \\ ${ }^{4}$ College of Veterinary Medicine, Konkuk University, Seoul 143-701, Korea
}

\begin{abstract}
Staphylococcus aureus lipase is regarded as a virulence factor. The response of lipase activity to various factors can provide important insights concerning the prevention of $S$. aureus during meat fermentation. This study was conducted to evaluate the main effects of nutrients used in culture media, and their combined effects on the inhibition of lipase activity and cell growth of pathogenic $S$. aureus SK1593 isolated from fermented pork meat. A Plackett-Burman design was used to evaluate the main effects of variables, including olive oil, soybean oil, grapeseed oil, sesame oil, $\mathrm{CuSO}_{4}, \mathrm{MgCl}_{2}, \mathrm{KNO}_{3}$, $\mathrm{CaCl}_{2}$, and $\mathrm{KCl}$. Significant negative effects on lipase activity were detected with soybean oil, grapeseed oil, $\mathrm{KNO}_{3}$, and $\mathrm{CaCl}_{2}$. Additionally, these nutrients were further selected as variables for the investigation of their combined effect on lipase activity, via response surface methodology. In order to confirm the regression model, a situation that only inhibits lipase activity was simulated. The predicted lipase activity and cell growth of the simulated situation were $14.0 \mathrm{U} / \mathrm{mL}$ and $9.6 \log _{10}$ $(\mathrm{CFU} / \mathrm{mL})$, respectively, and the estimated value of those in the same medium showed $15.14 \mathrm{U} / \mathrm{mL}$ and $9.4 \log _{10}(\mathrm{CFU} / \mathrm{mL})$ respectively. The lipase activity of the simulated medium was inhibited approximately 5-fold as compared to the basal medium, but no significant differences in cell counts were noted to exist between the basal and simulated media. These results suggest that soybean oil, grapeseed oil, $\mathrm{KNO}_{3}$, and $\mathrm{CaCl}_{2}$ can be used to inhibit the growth of pathogenic $S$. aureus during the process of meat fermentation.
\end{abstract}

Key words: Staphylococcus aureus SK1953, lipase activity, Plackett-Burman design, response surface model

\section{Introduction}

Meat products often contain pathogenic bacteria. For the effective preservation of sausage, fermentation processes have traditionally been used in its manufacture. Low-acid-fermentation following spontaneous fermentation without starter culture is preferred by the customers because of a dislike of an acidic taste. However, the risk of pathogenic bacteria is greater in low-acid-fermented than in high-acid-fermented sausage (Ananou et al., 2010).

Staphylococcus aureus is a representative meat-borne pathogen that is most frequently found in chopped meat mixtures or fermented sausage. This organism is tolerant to salt and nitrite, and is also able to grow under environ-

\footnotetext{
*Corresponding author: Soo-Ki Kim, Department of Animal Science and Environment, Konkuk University, Seoul 143-701, Korea. Tel: 82-2-450-3728, Fax: 82-458-3728, E-mail: sookikim@konkuk. ac.kr
}

mental conditions present in raw meat and in processing equipment (Ananou et al., 2010; Gonzáez-Fandos et al., 1999). To control or prevent the contamination of sausage by pathogenic bacteria, various additives such as sulfite, nitrite, alcohol and antibiotics, have been added during its manufacture (Jofré et al., 2008). However, the recent increasing preference for natural animal products by consumers has resulted in a the use of restricted chemical additives. Hence, the use of bacteriocin which is produced from lactic acid bacteria (LAB) is now the preferred preservative (Ananou et al., 2005). However, it is difficult to add LAB to low-acid-fermented meat or ready-to-eat sausage. The effective control of staphylococcal contamination is very important during meat processing.

The enzyme lipase of pathogenic bacteria is regarded as a control factor for the prevention of its colonization. Lipase has been shown to improve the adherence and colonization of pathogenic bacteria by degrading lipids on the external surface of the host, after that the liberated 
free fatty acids function as nutrients for the persistence of colonized bacteria (Grippa et al., 1999; Longshaw et al., 2000; Rosenstein and Götz, 2000). The lipase of $S$. aureus is also regarded as a virulence factor (Kuroda et al., 2007; Pereira et al., 2009). For these reasons, the response of lipase activity to various factors during bacterial growth can provide important insights concerning the control and prevention of pathogenic bacteria.

Most bacterial lipases are extracellular enzymes, and their activities are influenced by nutrients such as carbon, nitrogen, and mineral sources (Ebrahimpour et al., 2008; Joseph et al., 2006; Lakshmi et al., 1999; Rathi et al., 2002). Few studies of the inhibition of lipase activity using nutrient components of $S$. aureus have been conducted.

In the current study, we isolated S. aureus SK1953 from fermented pork meat and evaluated the effects of certain nutrients on its lipase activity. Two statistical methods-Plackett-Burman design and response surface methodology were used for the first time to determine the main effects of nutrients and their combined effects to inhibit the lipase activity of $S$. aureus SK1953. We found that some components, such as minerals and plant oils, had negative effects at lipase activity.

\section{Materials and Methods}

\section{Isolation of lipolytic strain}

Cooked pork meat was spontaneously fermented at room temperature for three days. It was suspended in sterilized $0.8 \%(\mathrm{w} / \mathrm{v}) \mathrm{NaCl}$ solution and homogenized with a blender (Philips, Holland). The suspended solution was subsequently diluted with the same buffer and spread onto LB (Difco, USA) agar plates. It was incubated overnight at $30^{\circ} \mathrm{C}$. Morphologically different colonies were then selected and streaked onto a lipolytic strain screening agar plate, then incubated overnight at $30^{\circ} \mathrm{C}$. The screening media was prepared via the addition of $1 \mathrm{~mL}$ of tributyrin to $100 \mathrm{~mL}$ of LB agar media, and was homogenized to minimize tributyrin droplets and increase turbidity. The lipolytic colony showing a large clear zone was isolated, then grown for $24 \mathrm{~h}$ in $\mathrm{LB}$ broth at $30^{\circ} \mathrm{C}$ for the preparation of the stock cultures. One hundred microliters of dimethyl sulfoxide (DMSO) were added to 0.9 $\mathrm{mL}$ of grown culture, and stored at below $-70^{\circ} \mathrm{C}$.

\section{Identification of isolated strain}

For the identification of the isolated strain, the $16 \mathrm{~S}$ rRNA gene sequence of the isolated strain was amplified using two universal primers (27F: 5'-AGA GTT TGA TCC TGG CTC AG-3', 1492R: 5'-GGT TAC CTT GTT ACG ACT T-3'). Next, the amplified sequence was analyzed with an ABI PRISM 3730XL DNA analyzer. All analyses were conducted at Solgent Co. Ltd (Korea, Daejun). Homology of the sequence of the isolated strain was searched in the GeneBank database, using the BLAST program. Multiple alignments were conducted using CLUSTAL_W software (Thompson et al., 1994) with 16S rRNA gene sequences of type strains involved in the same genus of the isolated strain as a result of the homology search. The construction of a phylogenetic tree to determine evolutionary distance was conducted via the Maximum Likelihood method in MEGA 4 (Tamura et al., 2007; Tamura et al., 2004).

\section{Medium preparation and culture conditions}

The inoculum was prepared via the streaking of a piece of frozen stock culture on a LB agar plate, followed by incubation at $30^{\circ} \mathrm{C}$ until colonies became visible. Then, a single colony was transferred to $5 \mathrm{~mL}$ of LB broth at $30^{\circ} \mathrm{C}$ for $24 \mathrm{~h}$ with shaking $(150 \mathrm{rpm})$ and used as an inoculum for the test culture. The basal medium employed for the screening of effective nutrients and their interaction contained $(\mathrm{g} / \mathrm{L})$ : beef extract, 10 ; yeast extract, 5 and $\mathrm{NaCl}, 5$. After the addition of all of the screening nutrients into basal medium in accordance with the experimental design to prepare the experimental medium, the $\mathrm{pH}$ of each medium was adjusted to 7.0 with $10 \mathrm{~N}$ $\mathrm{NaOH}$ and incubated for $24 \mathrm{~h}$ at $30^{\circ} \mathrm{C}$ with shaking (150 rpm). Two hundreds microliters of inoculum were transferred to $20 \mathrm{~mL}$ of experimental medium in $100 \mathrm{~mL}$ Erlenmeyer flasks. The media containing oil were homogenized (Ultra Turrax, Janke \& Kunkel, Germany) to minimize oil droplets prior to autoclaving.

\section{The assay of lipase activity}

Lipase activity was determined via a spectrophotometric assay using $p$-nitrophenyl butyrate ( $p \mathrm{NPB}$ ) as previously described with slight modification (Ryu et al., 2006). In brief, a reaction mixture composed of $10 \mu \mathrm{L}$ of $50 \mathrm{mM}$ $p$ NPB in acetonitrile, $40 \mu \mathrm{L}$ of ethanol, $950 \mu \mathrm{L}$ of $50 \mathrm{mM}$ Tris- $\mathrm{HCl}(\mathrm{pH} 8.0)$ and $50 \mu \mathrm{L}$ of culture supernatant was incubated at $37^{\circ} \mathrm{C}$ and the optical density at $405 \mathrm{~nm}$ was estimated at $1 \mathrm{~min}$ intervals until it reached a level of 0.5 . The concentration of liberated $p$-nitrophenyl was then calculated via regression of a standard $p$-nitrophenyl solution, and one unit was defined as one nM of $p$-nitrophenyl per min. 
Table 1. Variables showing nutrients and their high and low concentrations used in Plackett-Burman design

\begin{tabular}{clcc}
\hline \hline Variables & Nutrients & +1 values $(\mathrm{g} / \mathrm{L})$ & -1 values $(\mathrm{g} / \mathrm{L})$ \\
\hline $\mathrm{X}_{1}$ & Olive oil & 5 & 0.5 \\
$\mathrm{X}_{2}$ & Soybean oil & 5 & 0.5 \\
$\mathrm{X}_{3}$ & Grapeseed oil & 5 & 0.5 \\
$\mathrm{X}_{4}$ & Sesame oil & 5 & 0.5 \\
$\mathrm{X}_{5}$ & $\mathrm{CuSO}_{4}$ & 1 & 0.05 \\
$\mathrm{X}_{6}$ & $\mathrm{MgCl}_{2}$ & 1 & 0.05 \\
$\mathrm{X}_{7}$ & $\mathrm{KNO}_{3}$ & 1 & 0.05 \\
$\mathrm{X}_{8}$ & $\mathrm{CaCl}_{2}$ & 1 & 0.05 \\
$\mathrm{X}_{9}$ & $\mathrm{KCl}$ & 1 & 0.05 \\
\hline
\end{tabular}

\section{Determination of bacterial cell count}

The cell count in culture was determined via serial dilution, as previously described (Lappe et al., 2009) and was estimated as colony forming units $(\mathrm{CFU} / \mathrm{mL})$. Culture suspensions were diluted to $10^{-7}$ in sterilized $0.8 \%$ $(\mathrm{w} / \mathrm{v}) \mathrm{NaCl}$ solution and spread onto LB agar plates. The plates were then incubated for $24 \mathrm{~h}$ at $30^{\circ} \mathrm{C}$, and 30 to 100 colonies were counted. The cell counts were used as the logarithm of $\mathrm{CFU} / \mathrm{mL}$ to base 10 when evaluating the effects of the experiments.

\section{Screening of effective nutrients on lipase activity}

A Plackett-Burman design (Plackett and Burman, 1946) was used in this study to screen the important nutrients with regard to the major negative effects on lipase activity. A total of nine components (variable $k=$ 9) were employed, and two concentration levels were selected (Table 1). High and low levels of concentration were represented as sign (+1) and sign (-1), respectively. The Plackett-Burman design matrix with nine variables is shown in Table 2. Columns and rows represent variables and runs, respectively. In each of the runs, one of two signs of a variable was assigned and the number of high signs per run is $(k+1) / 2$, and that of the low sign is $(k-$ $1) / 2$. The effects of variables, their probability, and analysis of variance were calculated and the variables showing negative effect with $95 \%$ confidence level were selected for further experiment.

\section{Screening of interaction between selected nutrients}

Response surface methodology (RSM) was employed to assess the combined effects on selected nutrients that showed negative values in effect within a $95 \%$ confidence level from the results of the Plackett-Burman design experiment. A total of four nutrients were selected as variables and their three levels of concentration were assigned to each run. Twenty seven runs of a BoxBehnken (Box and Behnken, 1960) design with three replicates at the center point were employed. The coded and actual values of the variables assigned to each run are provided in Table 4. A quadratic equation was employed to explain the response of the system:

$$
Y=\beta_{0}+\sum \beta_{i} X_{i}+\sum \beta_{i} X_{i}^{2}+\sum \beta_{i j} X_{i} X_{j}
$$

where $Y$ is the predicted response, $\beta_{0}$ is the intercept, and $\beta_{\mathrm{i}}$ and $\beta_{\mathrm{ij}}$ are the regression coefficients. $X_{i}$ and $X_{j}$ are the independent variables $(i \neq j)$. Solution of the quadratic equation and analysis of variance were conducted via the use of response surface methodology.

\section{Statistical analysis}

Normality test of the observed results of lipase activity and cell counts assigned to each runs in Plackett-Burman

Table 2. Plackett-Burman design matrix of 12 runs with 9 variables and related responses

\begin{tabular}{|c|c|c|c|c|c|c|c|c|c|c|c|}
\hline \multirow{2}{*}{ Runs } & \multicolumn{9}{|c|}{ Variables } & \multirow{2}{*}{$\begin{array}{c}\text { Lipase activity }^{1)} \\
\mathrm{U} / \mathrm{mL}\end{array}$} & \multirow{2}{*}{$\begin{array}{c}\text { Cell count, } \\
\log _{10}(\mathrm{CFU} / \mathrm{mL})\end{array}$} \\
\hline & $\mathrm{X}_{1}$ & $\mathrm{X}_{2}$ & $X_{3}$ & $\mathrm{X}_{4}$ & $\mathrm{X}_{5}$ & $\mathrm{X}_{6}$ & $\mathrm{X}_{7}$ & $\mathrm{X}_{8}$ & $\mathrm{X}_{9}$ & & \\
\hline 1 & 1 & -1 & 1 & -1 & -1 & -1 & 1 & 1 & 1 & 7.35 & 6.50 \\
\hline 2 & 1 & 1 & -1 & 1 & -1 & -1 & -1 & 1 & 1 & 27.01 & 6.99 \\
\hline 3 & -1 & 1 & 1 & -1 & 1 & -1 & -1 & -1 & 1 & 16.33 & 5.30 \\
\hline 4 & 1 & -1 & 1 & 1 & -1 & 1 & -1 & -1 & -1 & 24.60 & 7.26 \\
\hline 5 & 1 & 1 & -1 & 1 & 1 & -1 & 1 & -1 & -1 & 26.74 & 5.54 \\
\hline 6 & 1 & 1 & 1 & -1 & 1 & 1 & -1 & 1 & -1 & 15.30 & 4.26 \\
\hline 7 & -1 & 1 & 1 & 1 & -1 & 1 & 1 & -1 & 1 & 24.57 & 6.45 \\
\hline 8 & -1 & -1 & 1 & 1 & 1 & -1 & 1 & 1 & -1 & 19.95 & 4.22 \\
\hline 9 & -1 & -1 & -1 & 1 & 1 & 1 & -1 & 1 & 1 & 44.76 & 4.12 \\
\hline 10 & 1 & -1 & -1 & -1 & 1 & 1 & 1 & -1 & 1 & 30.43 & 3.92 \\
\hline 11 & -1 & 1 & -1 & -1 & -1 & 1 & 1 & 1 & -1 & 6.99 & 5.40 \\
\hline 12 & -1 & -1 & -1 & -1 & -1 & -1 & -1 & -1 & -1 & 7.17 & 9.47 \\
\hline
\end{tabular}

\footnotetext{
${ }^{1}$ Lipase activity was defined as nanomole of $p$-nitropheny liberated from p-nitrophenyl-butyrate per one min.
} 


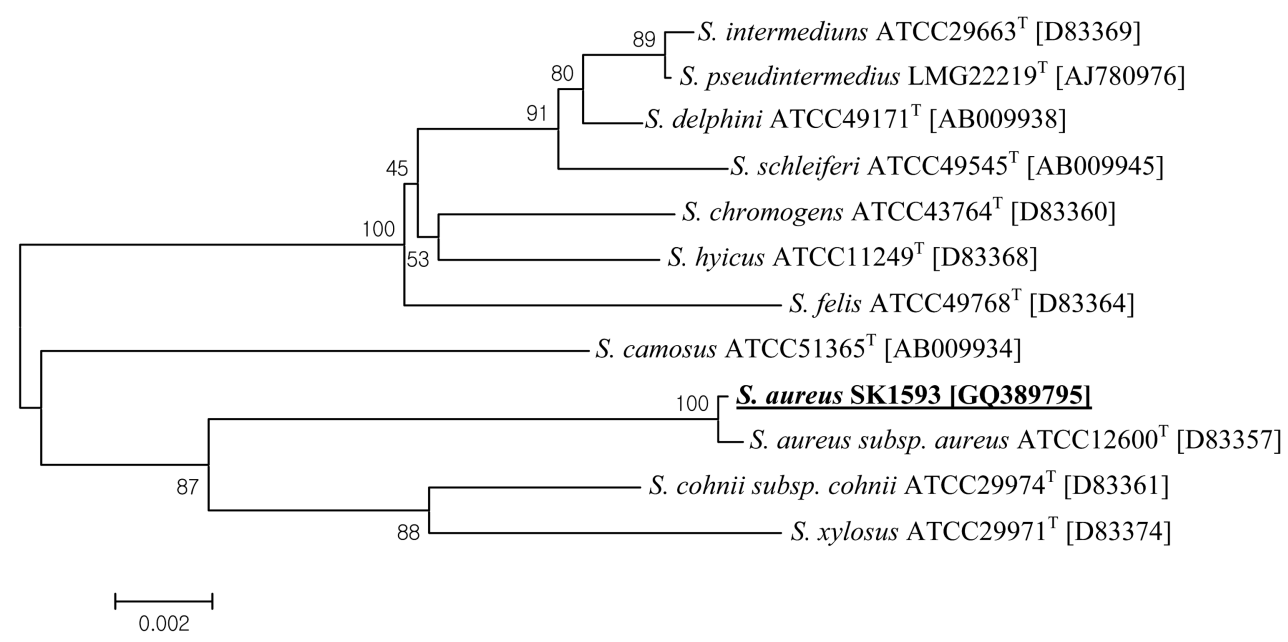

Fig. 1. Phylogenic tree based on the 16S rRNA sequence of Staphylococcus aureus SK1593 and other type strains of staphylococci. Bootstrap values (based on 1,000 trials and only values $>50 \%$ ) are shown at the nodes. Bar, 0.002 substitutions per nucleotide position.

design and Box-Benken design were employed with Anderson-Darling method prior to performing the analysis of variance. MINITAB ${ }^{\circledR}$ program (version 14.0 , Minitab Inc., USA) was used for the calculation of normality test of responses of each experiment, the effects of variables, their probability and analysis of variance in Plackett-Burmen design experiment, a response surface methodology and a multiple response optimizer with the responses of Box-Benhken design experiment. The significance levels of the differences between cell count and lipase activity of basal medium and those of simulated medium in the experiment of prediction and validation of model were determined using Student $t$-test.

\section{Results and Discussion}

\section{Screening and isolation of a lipolytic strain from fermented pork meat}

Three colonies showing a clear zone surrounding the growth on LB-tributyrin were detected and the colony with the largest clear zone among them was selected. With the 16S rRNA gene sequence of the isolate, the homology was searched in the GenBank database, and a high level of identity with Staphylococcus aureus was assessed. Then, a multiple alignment with 11 species of staphylococcal-type strains was conducted in order to analyze the evolutionary distance and to construct a phylogenetic tree for identification. Finally, the isolated strain was determined to be closely related to Staphylococcus aureus subsp. aureus ATCC $12600^{\mathrm{T}}$, with an identity of $99.7 \%$ (Fig. 1), and was named Staphylococcus aureus SK1593 (GenBank accession no. GQ389795)

\section{Screening of effective nutrients to inhibit lipase activity}

Prior to evaluating the effect of nutrients on the lipase activity of Staphylococcus aureus SK1953, a lipase assay was conducted with buffer solution at various $\mathrm{pH}$ values in order to optimize the assay conditions. The $\mathrm{pH}$ of buffer solution varied from 3.0 to 9.0, and the overnight culture supernatants of $S$. aureus SK1953 cultivated in basal medium were employed for the assay. The highest level of activity was detected at a $\mathrm{pH}$ of 8.0, and subsequent analyses were conducted at $\mathrm{pH}$ 8.0. The PlackettBurman design is a convenient and accurate statistical method that involves relatively small numbers of experiments (runs) when only the main effects of variables, rather than their combined effects, were considered (Chauhan et al., 2007; Plackett and Burman, 1946). The nutrients were used as independent variables which are represented with their respective high and low concentrations, as is shown in Table 1. The Plackett-Burman design matrix with 9 nutrients as variables and their related responses (lipase activity and cell count) is shown in Table 2. In normality test of responses assigned to each runs, the $p$ value of lipase activity and cell count were 0.432 and 0.330 , respectively. The results of the experiment with regard to lipase activity, the effect, standard error, $t$ value, $p$ value, and analysis of variance are presented in Table 3. All of the nutrients showed significance at a confidence level in excess of $95 \%$. The $p$ value of the main effect in analysis of variance was 0.002 , which 
Table 3. ANOVA (Analysis of variance) of experiment and effects of media components on the lipase activity of $S$. aureus SK1593 as determined by 12 runs based on the Plackett-Burman design

\begin{tabular}{|c|c|c|c|c|c|}
\hline$\overline{\text { Items }}$ & $\mathrm{DF}^{1)}$ & $\mathrm{SS}^{2)}$ & $\mathrm{MS}^{3)}$ & & $P>F$ \\
\hline Main effect & 9 & 1376.8 & $153.0 \quad 629$ & & 0.002 \\
\hline $\begin{array}{l}\text { Residual } \\
\text { error }\end{array}$ & 2 & 0.5 & 0.2 & & \\
\hline Total & 11 & 1377.2 & & & \\
\hline \multirow{2}{*}{ Variables } & \multirow{2}{*}{ Effect } & \multicolumn{2}{|c|}{ Coefficient } & \multirow{2}{*}{$t$ value } & \multirow{2}{*}{$p$ value } \\
\hline & & Effect & $\mathrm{SE}^{4)}$ & & \\
\hline Constant & & 20.935 & 0.1423 & 147.13 & $3<0.001$ \\
\hline Olive oil & 1.944 & 0.972 & 0.1423 & 6.83 & 0.021 \\
\hline Soybean oil & -2.885 & -1.443 & 0.1423 & -10.14 & 0.010 \\
\hline Grapeseed oil & -5.837 & -2.918 & 0.1423 & -20.51 & 0.002 \\
\hline Sesame oil & 14.008 & 7.004 & 0.1423 & 49.22 & $<0.001$ \\
\hline $\mathrm{CuSO}_{4}$ & 9.302 & 4.651 & 0.1423 & 32.69 & 0.001 \\
\hline $\mathrm{MgCl}_{2}$ & 7.018 & 3.509 & 0.1423 & 24.66 & 0.002 \\
\hline $\mathrm{KNO}_{3}$ & -3.190 & -1.595 & 0.1423 & -11.21 & 0.008 \\
\hline $\mathrm{CaCl}_{2}$ & -1.413 & -0.707 & 0.1423 & -4.97 & 0.038 \\
\hline $\mathrm{KCl}$ & 8.280 & 4.140 & 0.1423 & 29.10 & 0.001 \\
\hline
\end{tabular}

${ }^{1)} \mathrm{DF}$, degree of freedom.

${ }^{2)} \mathrm{SS}$, sum of square.

${ }^{3)} \mathrm{MS}$, mean of square.

${ }^{4)} \mathrm{SE}$, standard error.

indicates that the result of the experiment reflected adequate for the screening of the main effects of variables. Olive oil, sesame oil, $\mathrm{CuSO}_{4}, \mathrm{MgCl}_{2}$, and $\mathrm{KCl}$ showed positive effects, thus demonstrating that these nutrients are capable of increasing lipase activity with increased concentration. Conversely, soybean oil, grapeseed oil, $\mathrm{KNO}_{3}$, and $\mathrm{CaCl}_{2}$ evidenced a negative effect, which indicates that an increase in these nutrients can reduce lipase activity. A variety of oil sources have been investigated in order to evaluate their effects on staphylococcal lipase activity, and they have been identified as excellent inducers of lipase activity (Gupta et al., 2004; Hasanuzzaman et al., 2004). A 1\% supplementation of olive oil resulted in an increase of more than two-fold in the lipase activity of Staphylococcus epidermidis (Joseph et al., 2006). However, the opposite results also have been noted in other studies (Al-Waili, 2005; Walavalkar and Bapat, 2002). In this study, olive and sesame oils exerted positive effects, whereas soybean and grapeseed oils exerted a negative effect on the lipase activity of S. aureus SK1593. In previous reports, calcium chloride has generally been regarded as an excellent lipase inducer, as it is capable of stabilizing the three-dimensional structure of the lipolytic enzyme during the reaction by binding to free fatty acid liberated during lipid hydrolysis (Gupta et al., 2004;
Longshaw et al., 2000). However, in this study, it was shown to exert a negative effect on lipase activity. The effects of nutrients on the growth of Staphylococcus aureus SK1593 were also evaluated. However, the $p$ value of the main effect from analysis of variance was 0.145 , which indicates that the evaluation of the main effect with this experiment was not proper. Therefore, the effects of nutrients on growth were not considered in the following experiments.

\section{Interaction of selected nutrients}

We determined that soybean oil, grapeseed oil, $\mathrm{KNO}_{3}$, and $\mathrm{CaCl}_{2}$ can inhibit lipase activity within a $95 \%$ confidence level, via an experiment based on a Plackett-Burman design. These nutrients were selected for subsequent experiments because the objective of this study was to determine the response of lipase to various nutrients and to identify negatively effective nutrients in order to reduce staphylococcal lipase activity. Furthermore, these nutrients were employed to evaluate their combined effects using RSM. Twenty seven runs of the BoxBehnken design with different combinations of the four selected nutrients were conducted. Table 4 shows the Box-Behnken design matrix including the selected variables, their coded values, assigned actual concentrations, and the results of estimated and predicted responses (lipase activity and cell growth). In normality test of responses assigned to each runs, the $p$ value of lipase activity and cell count were 0.979 and 0.218 , respectively. The responses were analyzed via quadratic multiple regressions, and the following equations were obtained for lipase activity and cell growth:

$$
\begin{aligned}
Y_{\text {lipase }}= & 5.43+3.44 X_{1}+7.01 X_{2}+2.25 X_{3}+35.50 X_{4}-0.26 X_{1}^{2} \\
& -0.99 X_{2}^{2}+0.84 X_{3}^{2}-28.00 X_{4}^{2}-0.51 X_{1} X_{2}+0.66 X_{1} X_{3}+ \\
& 0.17 X_{1} X_{4}-0.83 X_{2} X_{3}+0.33 X_{2} X_{4}-9.17 X_{3} X_{4} \\
Y_{\text {cellcount }}= & 8.34-0.13 X_{1}+0.07 X_{2}+1.39 X_{3}+2.83 X_{4}+0.02 X_{1}^{2} \\
& -0.03 X_{2}^{2}-1.23 X_{3}^{2}-2.71 X_{4}^{2}-0.005 X_{1} X_{2}+0.03 X_{1} X_{3}+ \\
& 0.03 X_{1} X_{4}-0.13 X_{2} X_{3}+0.13 X_{2} X_{4}+0.06 X_{3} X_{4}
\end{aligned}
$$

where $Y_{\text {lipase }}$ and $Y_{\text {cellcount }}$ are the predicted responses of lipase activity and cell growth, respectively. With regard to cell growth, the response was represented as the logarithm of CFU/mL to base 10. $X_{1}, X_{2}, X_{3}$ and $X_{4}$ are the uncoded values $(\mathrm{g} / \mathrm{L})$ of variables for soybean oil, grapeseed oil, $\mathrm{KNO}_{3}$, and $\mathrm{CaCl}_{2}$, respectively. The results were evaluated via analysis of variance in order to validate the 
Table 4. Box-Behnken design configuration with coded and actual values for lipase activity and cell counts of $S$. aureus SK1593

\begin{tabular}{|c|c|c|c|c|c|c|c|c|c|c|c|c|}
\hline \multirow{2}{*}{ Runs } & \multicolumn{2}{|c|}{ Soybean oil, g/L } & \multicolumn{2}{|c|}{ Grapeseed oil, g/L } & \multicolumn{2}{|c|}{$\mathrm{KNO}_{3}, \mathrm{~g} / \mathrm{L}$} & \multicolumn{2}{|c|}{$\mathrm{CaCl}_{2}, \mathrm{~g} / \mathrm{L}$} & \multicolumn{2}{|c|}{$\begin{array}{c}\text { Lipase activity, } \\
\mathrm{U} / \mathrm{mL}\end{array}$} & \multicolumn{2}{|c|}{$\begin{array}{c}\text { Cell count, } \\
\log _{10}(\mathrm{CFU} / \mathrm{mL})\end{array}$} \\
\hline & $\begin{array}{l}\text { Coded } \\
\text { value }\end{array}$ & $\begin{array}{l}\text { Actual } \\
\text { value }\end{array}$ & $\begin{array}{l}\text { Coded } \\
\text { value }\end{array}$ & $\begin{array}{l}\text { Actual } \\
\text { value }\end{array}$ & $\begin{array}{l}\text { Coded } \\
\text { value }\end{array}$ & $\begin{array}{l}\text { Actual } \\
\text { value }\end{array}$ & $\begin{array}{l}\text { Coded } \\
\text { value }\end{array}$ & $\begin{array}{l}\text { Actual } \\
\text { value }\end{array}$ & $\begin{array}{c}\text { Actual } \\
\text { value }\end{array}$ & $\begin{array}{l}\text { Predicted } \\
\text { value }\end{array}$ & $\begin{array}{c}\text { Actual } \\
\text { value }\end{array}$ & $\begin{array}{c}\text { Predicted } \\
\text { value }\end{array}$ \\
\hline 1 & -1 & 0.50 & -1 & 0.50 & 0 & 0.53 & 0 & 0.53 & 14.66 & 20.10 & 9.71 & 9.58 \\
\hline 2 & 1 & 5.00 & -1 & 0.50 & 0 & 0.53 & 0 & 0.53 & 28.14 & 29.91 & 9.55 & 9.59 \\
\hline 3 & -1 & 0.50 & 1 & 5.00 & 0 & 0.53 & 0 & 0.53 & 23.89 & 24.95 & 8.92 & 9.02 \\
\hline 4 & 1 & 5.00 & 1 & 5.00 & 0 & 0.53 & 0 & 0.53 & 26.96 & 24.36 & 8.67 & 8.94 \\
\hline 5 & 0 & 2.75 & 0 & 2.75 & -1 & 0.05 & -1 & 0.05 & 24.36 & 22.70 & 8.33 & 8.23 \\
\hline 6 & 0 & 2.75 & 0 & 2.75 & 1 & 1.00 & -1 & 0.05 & 22.47 & 24.79 & 7.80 & 8.05 \\
\hline 7 & 0 & 2.75 & 0 & 2.75 & -1 & 0.05 & 1 & 1.00 & 28.85 & 29.36 & 9.16 & 9.05 \\
\hline 8 & 0 & 2.75 & 0 & 2.75 & 1 & 1.00 & 1 & 1.00 & 18.68 & 23.18 & 8.69 & 8.93 \\
\hline 9 & -1 & 0.50 & 0 & 2.75 & -1 & 0.05 & 0 & 0.53 & 30.98 & 29.43 & 9.11 & 9.30 \\
\hline 10 & 1 & 5.00 & 0 & 2.75 & -1 & 0.05 & 0 & 0.53 & 34.05 & 32.63 & 9.00 & 9.21 \\
\hline 11 & -1 & 0.50 & 0 & 2.75 & 1 & 1.00 & 0 & 0.53 & 29.58 & 25.98 & 9.29 & 9.09 \\
\hline 12 & 1 & 5.00 & 0 & 2.75 & 1 & 1.00 & 0 & 0.53 & 35.47 & 31.99 & 9.28 & 9.11 \\
\hline 13 & 0 & 2.75 & -1 & 0.50 & 0 & 0.53 & -1 & 0.05 & 23.41 & 19.10 & 8.78 & 8.68 \\
\hline 14 & 0 & 2.75 & 1 & 5.00 & 0 & 0.53 & -1 & 0.05 & 19.86 & 18.04 & 7.85 & 7.80 \\
\hline 15 & 0 & 2.75 & -1 & 0.50 & 0 & 0.53 & 1 & 1.00 & 24.12 & 20.92 & 9.20 & 9.27 \\
\hline 16 & 0 & 2.75 & 1 & 5.00 & 0 & 0.53 & 1 & 1.00 & 21.99 & 21.27 & 8.81 & 8.92 \\
\hline 17 & -1 & 0.50 & 0 & 2.75 & 0 & 0.53 & -1 & 0.05 & 19.16 & 20.11 & 8.46 & 8.56 \\
\hline 18 & 1 & 5.00 & 0 & 2.75 & 0 & 0.53 & -1 & 0.05 & 19.86 & 24.37 & 8.57 & 8.47 \\
\hline 19 & -1 & 0.50 & 0 & 2.75 & 0 & 0.53 & 1 & 1.00 & 24.59 & 22.28 & 9.42 & 9.36 \\
\hline 20 & 1 & 5.00 & 0 & 2.75 & 0 & 0.53 & 1 & 1.00 & 26.01 & 27.24 & 9.63 & 9.38 \\
\hline 21 & 0 & 2.75 & -1 & 0.50 & -1 & 0.05 & 0 & 0.53 & 25.54 & 26.65 & 9.11 & 9.15 \\
\hline 22 & 0 & 2.75 & 1 & 5.00 & -1 & 0.05 & 0 & 0.53 & 25.07 & 28.07 & 9.04 & 8.81 \\
\hline 23 & 0 & 2.75 & -1 & 0.50 & 1 & 1.00 & 0 & 0.53 & 27.20 & 26.38 & 9.20 & 9.27 \\
\hline 24 & 0 & 2.75 & 1 & 5.00 & 1 & 1.00 & 0 & 0.53 & 23.18 & 24.25 & 8.58 & 8.38 \\
\hline 25 & 0 & 2.75 & 0 & 2.75 & 0 & 0.53 & 0 & 0.53 & 29.32 & 31.14 & 9.28 & 9.35 \\
\hline 26 & 0 & 2.75 & 0 & 2.75 & 0 & 0.53 & 0 & 0.53 & 31.22 & 31.14 & 9.47 & 9.35 \\
\hline 27 & 0 & 2.75 & 0 & 2.75 & 0 & 0.53 & 0 & 0.53 & 32.87 & 31.14 & 9.32 & 9.35 \\
\hline
\end{tabular}

regression coefficient. In the RSM for lipase activity, the lack of fit, model $F$, and model $P>F$ were found to be $0.165,2.27$, and 0.08 , respectively, and the determination coefficient $\left(R^{2}\right)$ was $72.6 \%$. In the RSM for cell growth, the lack of fit, model $F$, and model $P>F$ were found to be $0.150,7.73$ and 0.001 , and the determination coefficient $\left(R^{2}\right)$ was $90.0 \%$. In this study, the model for cell growth exhibited better fit than that of lipase activity. Figs. 2 and 3 represent the interaction of each of the two nutrients on lipase activity and cell growth, respectively. The combined effects of the two variables were explained using three-dimensional plots, which were prepared with the regression model coefficients evaluated by the uncoded values of variables. When the combined effects of the two variables were calculated, the other remaining variables were fixed at their central point assigned to the coded value of 0 , as shown in Table 4 . In the lipase response, a dual quadratic interaction was found between grapeseed oil and $\mathrm{CaCl}_{2}$ (Fig. 2E). The lowest level of lipase inhibition was detected in the combination of grapeseed oil and $\mathrm{CaCl}_{2}$, at approximately $2.5 \mathrm{~g} / \mathrm{L}$ and $0.5 \mathrm{~g} / \mathrm{L}$, respectively. In regard to the response of cell growth, a dual quadratic interaction was derived between $\mathrm{KNO}_{3}$ and $\mathrm{CaCl}_{2}$ (Fig. 3F).

\section{Prediction and validation of the model}

To validate the model, we simulated a situation - a combination of nutrients - in which lipase activity was inhibited without any inhibition of cell growth by using multiple response optimizer in MINITAB ${ }^{\circledR}$. The simulated medium was composed of the following $(\mathrm{g} / \mathrm{L})$ : soybean oil, 0.5 ; grapeseed oil, $0.5 ; \mathrm{KNO}_{3}, 0.5 ; \mathrm{CaCl}_{2}, 1.0$ in basal medium. The predicted values of lipase activity $\left(Y_{\text {lipase }}\right)$ and cell count $\left(Y_{\text {cellcount }}\right)$ from the simulated medium were calculated as $14.0 \mathrm{U} / \mathrm{mL}$ and $9.6 \log _{10}$ $(\mathrm{CFU} / \mathrm{mL})$, respectively. The preparation and culture conditions for the simulated medium were conducted as described in the 'Materials and Methods' section. The 
(A)

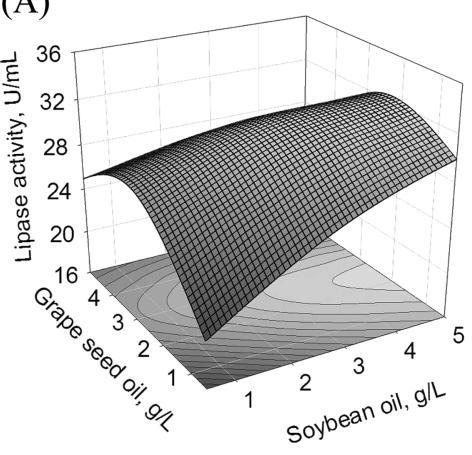

Fixed variables: $\mathrm{KNO}_{3}, \mathrm{CaCl}_{2}$

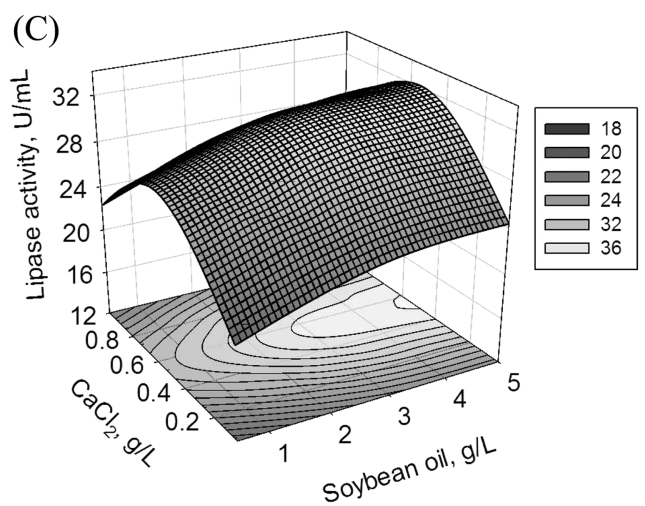

Fixed variables: Grape seed oil, $\mathrm{KNO}_{3}$

(E)

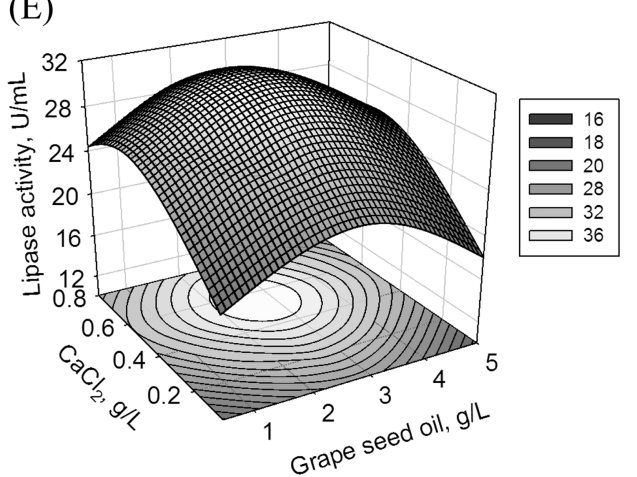

Fixed variables: Soybean oil, $\mathrm{KNO}_{3}$
(B)

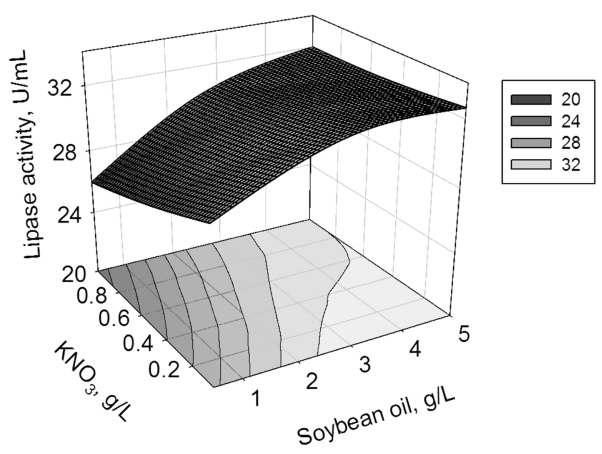

Fixed variables: Grape seed oil, $\mathrm{CaCl}_{2}$

(D)

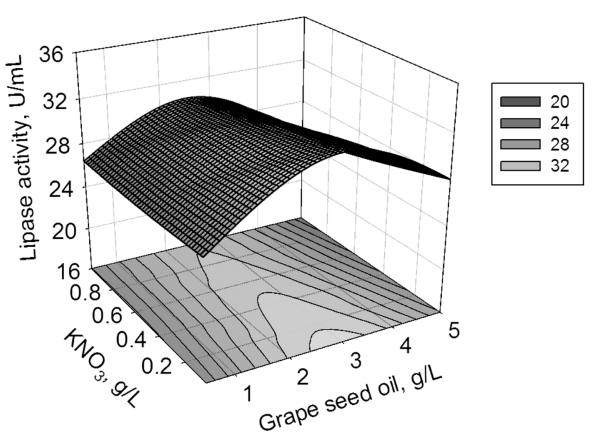

Fixed variables: soybean oil, $\mathrm{CaCl}_{2}$

(F)

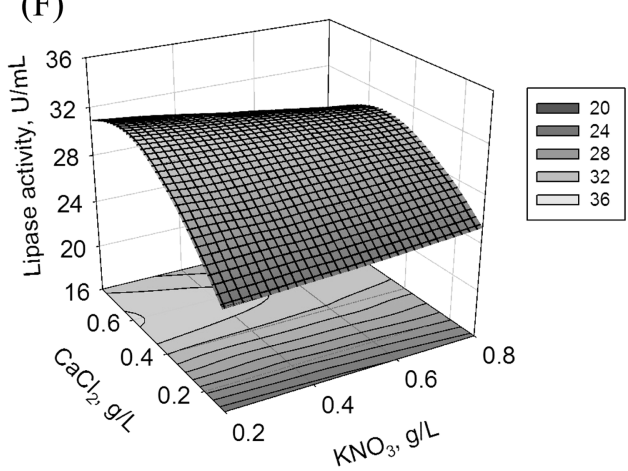

Fixed variables: Soybean oil, Grape seed oil

Fig. 2. Three-dimensional plot showing the effect of nutrients on lipase activity. (A) effects of soybean oil and grapeseed oil at the central point of $\mathrm{KNO}_{3}$ and $\mathrm{CaCl}_{2} ;$ (B) effect of soybean oil and $\mathrm{KNO}_{3}$ at central point of grapeseed oil and $\mathrm{CaCl}$; (C) effect of soybean oil and $\mathrm{CaCl}_{2}$ at the central point of grapeseed oil and $\mathrm{KNO}_{3} ;$ (D) effect of grapeseed oil and $\mathrm{KNO}_{3}$ at the central point of soybean oil and $\mathrm{CaCl}_{2} ;(\mathrm{E})$ effect of grapeseed oil and $\mathrm{CaCl}_{2}$ at the central point of soybean oil and $\mathrm{KNO}_{3}$; $(\mathrm{F})$ effect of $\mathrm{KNO}_{3}$ and $\mathrm{CaCl}_{2}$ at the central point of soybean and grapeseed oils.

results of lipase activity and cell growths were compared with those of basal medium (Table 5), and their significances were determined via the Student's $t$-test. On basal medium, the cell count and lipase activity were measured at $9.75 \pm 0.08 \log _{10}(\mathrm{CFU} / \mathrm{mL})$ and $73.31 \pm 2.95 \mathrm{U} / \mathrm{mL}$, respectively. The cell count $(9.37 \pm 0.18)$ of simulated medium was slightly lower than that of basal medium, but no significant differences were detected. However, the lipase activity of simulated medium $(15.14 \pm 0.82)$ was significantly lower than that of the basal medium. These results were quite similar to the predicted value.

Our results showed that soybean oil, grapeseed oil, $\mathrm{KNO}_{3}$, and $\mathrm{CaCl}_{2}$ exerted negative effects on the lipase activity of $S$. aureus SK1953. These components can be sprayed on meat surfaces during the fermentation process or added directly to the meat mixture, including pork meat 


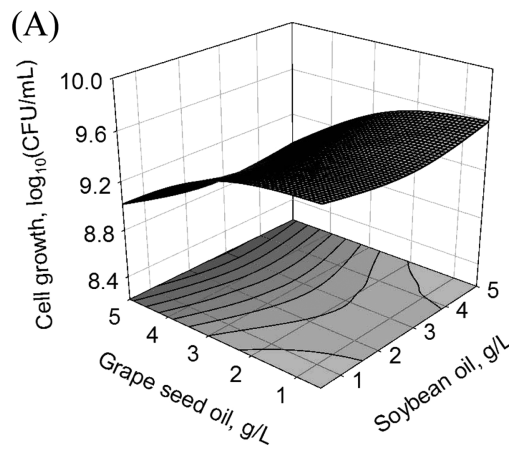

Fixed variables: $\mathrm{KNO}_{3}, \mathrm{CaCl}_{2}$

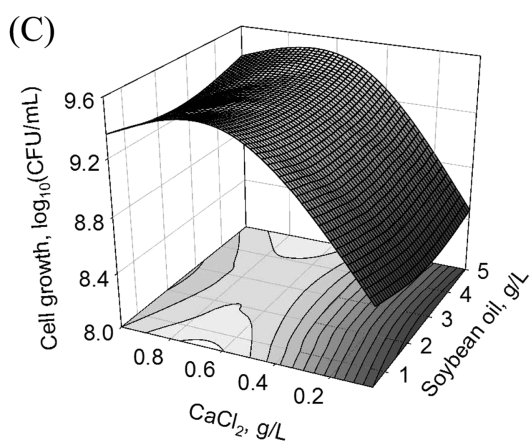

Fixed variables: Grape seed oil, $\mathrm{KNO}_{3}$

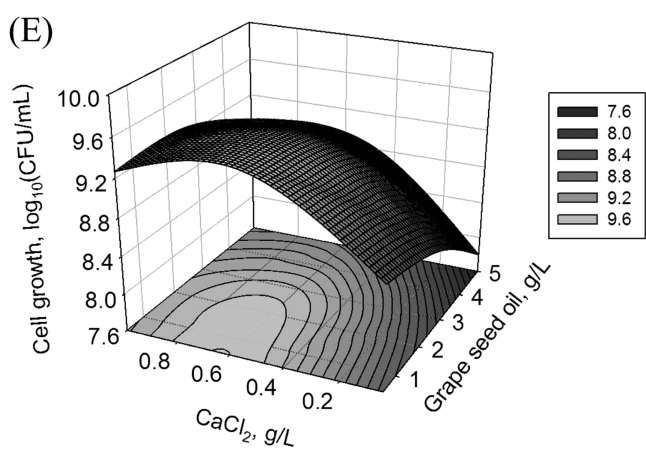

Fixed variables: Soybean oil, $\mathrm{KNO}_{3}$

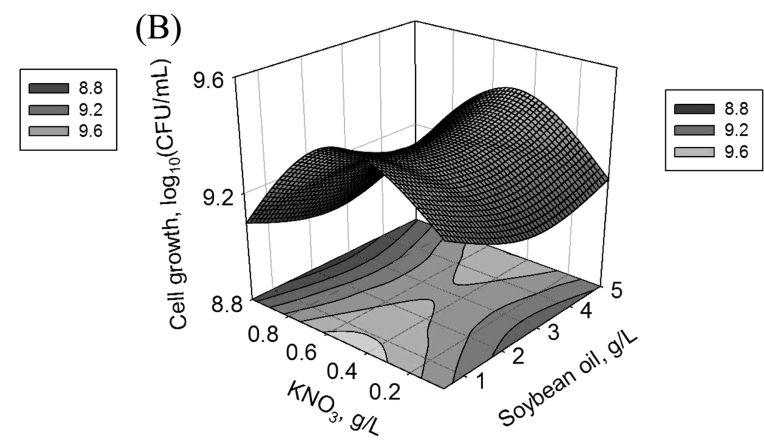

Fixed variables: Grape seed oil, $\mathrm{CaCl}_{2}$

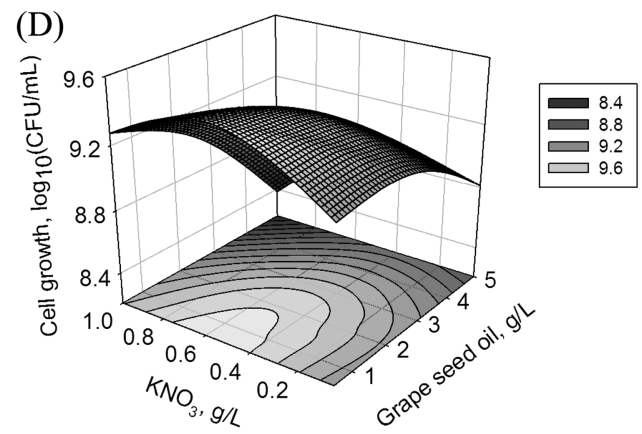

Fixed variables: soybean oil, $\mathrm{CaCl}_{2}$

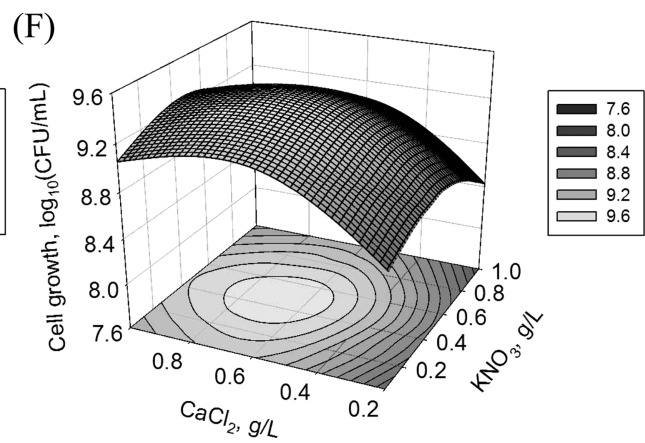

Fixed variables: Soybean oil, Grape seed oil

Fig. 3. Three-dimensional plot showing the effect of nutrients on cell count. (A) effect of soybean oil and grapeseed oil at the central point of $\mathrm{KNO}_{3}$ and $\mathrm{CaCl}_{2}$; (B) effect of soybean oil and $\mathrm{KNO}_{3}$ at the central point of grapeseed oil and $\mathrm{CaCl}_{2} ;(\mathrm{C})$ effect of soybean oil and $\mathrm{CaCl}_{2}$ at the central point of grapeseed oil and $\mathrm{KNO}_{3}$; (D) effect of grapeseed oil and $\mathrm{KNO}_{3}$ at the central point of soybean oil and $\mathrm{CaCl}_{2} ;(\mathrm{E})$ effect of grapeseed oil and $\mathrm{CaCl}_{2}$ at the central point of soybean oil and $\mathrm{KNO}_{3} ;(\mathrm{F})$ effect of $\mathrm{KNO}_{3}$ and $\mathrm{CaCl}_{2}$ at central point of soybean and grapeseed oils.

Table 5. Lipase activity and cell growth of basal and simulated media

\begin{tabular}{lcccc}
\hline \hline & Basal medium $^{1)}$ & Simulated medium $^{2)}$ & $t$ value & $p$ value \\
\hline Cell count, $\log _{10}(\mathrm{CFU} / \mathrm{mL})$ & $9.75 \pm 0.08^{3)}$ & $9.37 \pm 0.18$ & 2.52 & 0.128 \\
Lipase activity, $\mathrm{U} / \mathrm{mL}$ & $73.31 \pm 2.95$ & $15.14 \pm 0.82$ & 35.51 & 0.001 \\
\hline
\end{tabular}

${ }^{1)}$ Basal medium was consisted of $(\mathrm{g} / \mathrm{L})$ beef extract, 10 ; yeast extract, 5 and $\mathrm{NaCl}, 5 .{ }^{2}$ Simulated medium was consisted of $\left(\mathrm{g} \mathrm{l}^{-1}\right)$ beef extract, 10; yeast extract, 5; $\mathrm{NaCl}$, 5; soybean oil, 0.5; grapeseed oil, $0.5 ; \mathrm{KNO}_{3}, 0.5$ and $\mathrm{CaCl}_{2}$.

${ }^{3)}$ Mean \pm standard deviation from triplicates.

to inhibit the growth of pathogenic S. aureus. Artificial contamination experiments with $S$. aureus are needed to verify the growth-inhibiting effects of these components.

\section{Acknowledgement}

This work was supported by Institute of Biomedical Science and Technology (IBST-2004-1) of Konkuk University. 


\section{References}

1. Al-Waili, N. S. (2005) Mixture of honey, beeswax and olive oil inhibits growth of Staphylococcus aureus and Candida albicans. Arch. Med. Res. 36, 10-13.

2. Ananou, S., Garriga, M., Jofré, A., Aymerich, T., Gávez, A., Maqueda, M., Martíez-Bueno, M., and Valdivia, E. (2010) Combined effect of enterocin AS-48 and high hydrostatic pressure to control food-borne pathogens inoculated in low acid fermented sausages. Meat Sci. 84, 594-600.

3. Ananou, S., Maqueda, M., Martíez-Bueno, M., Gávez, A., and Valdivia, E. (2005) Control of Staphylococcus aureus in sausages by enterocin AS-48. Meat Sci. 71, 549-556.

4. Box, G. E. P., and Behnken, D. W. (1960) Some new three level designs for the study of quantitative variables. Technometrics. 2, 455-475.

5. Chauhan, K., Trivedi, U., and Patel, K. C. (2007) Statistical screening of medium components by Plackett-Burman design for lactic acid production by Lactobacillus sp. KCP01 using date juice. Bioresour. Technol. 98, 98-103.

6. Ebrahimpour, A., Rahman, R., Ean Ch'ng, D., Basri, M., and Salleh, A. (2008) A modeling study by response surface methodology and artificial neural network on culture parameters optimization for thermostable lipase production from a newly isolated thermophilic Geobacillus sp. strain ARM. BMC Biotech. 8, 96-101.

7. Gonzáez-Fandos, M. E., Sierra, M., Garcí-Lopez, M. L., Garcí-Fernádez, M. C., and Otero, A. (1999) The influence of manufacturing and drying conditions on the survival and toxinogenesis of Staphylococcus aureus in two Spanish dry sausages (chorizo and salchichón). Meat Sci. 52, 411-419.

8. Grippa, E., Valla, R., Battinelli, L., Mazzanti, G., Saso, L., and Silvestrini, B. (1999) Inhibition of Candida rugosa lipase by berberine and structurally related alkaloids, evaluated by high-performance liquid chromatography. Biosci. Biotechnol. Biochem. 63, 1557-1562.

9. Gupta, R., Gupta, N., and Rathi, P. (2004) Bacterial lipases: an overview of production, purification and biochemical properties. Appl. Microbiol. Biotechnol. 64, 763-781.

10. Hasanuzzaman, M., Umadhay-Briones, K. M., Zsiros, S. M., Morita, N., Nodasaka, Y., Yumoto, I., and Okuyama, H. (2004) Isolation, identification, and characterization of a novel, oil-degrading bacterium, Pseudomonas aeruginosa T1. Curr. Microbiol. 49, 108-114.

11. Jofré, A., Aymerich, T., and Garriga, M. (2008) Assessment of the effectiveness of antimicrobial packaging combined with high pressure to control Salmonella sp. in cooked ham. Food Control. 19, 634-638.

12. Joseph, B., Ramteke, P. W., and Kumar, P. A. (2006) Studies on the enhanced production of extracellular lipase by Staphylococcus epidermidis. J. Gen. Appl. Microbiol. 52, 315-320.

13. Kuroda, M., Nagasaki, S., Ito, R., and Ohta, T. (2007) Ses- quiterpene farnesol as a competitive inhibitor of lipase activity of Staphylococcus aureus. FEMS Microbiol. Lett. 273, 28-34.

14. Lakshmi, B. S., Kangueane, P., Abraham, B., and Pennathur, G. (1999) Effect of vegetable oils in the secretion of lipase from Candida rugosa (DSM 2031). Lett. Appl. Microbiol. 29, 66-70.

15. Lappe, R., Motta, A. S., Sant'Anna, V., and Brandelli, A. (2009) Inhibition of Salmonella enteritidis by cerein 8A, EDTA and sodium lactate. Int. J. Food Microbiol. 135, 312316.

16. Longshaw, C. M., Farrell, A. M., Wright, J. D., and Holland, K. T. (2000) Identification of a second lipase gene, gehD, in Staphylococcus epidermidis: comparison of sequence with those of other staphylococcal lipases. Microbiology. 146, 1419-1427.

17. Pereira, V., Lopes, C., Castro, A., Silva, J., Gibbs, P., and Teixeira, P. (2009) Characterization for enterotoxin production, virulence factors, and antibiotic susceptibility of Staphylococcus aureus isolates from various foods in Portugal. Food Microbiol. 26, 278-282.

18. Plackett, R. L., and Burman, J. P. (1946) The design of optimum multifactorial experiments. Biometrika. 33, 305-325.

19. Rathi, P., Goswami, V. K., Sahai, V., and Gupta, R. (2002) Statistical medium optimization and production of a hyperthermostable lipase from Burkholderia cepacia in a bioreactor. J. Appl. Microbiol. 93, 930-936.

20. Rosenstein, R., and Götz, F. (2000) Staphylococcal lipases: Biochemical and molecular characterization. Biochimie. 82, 1005-1014.

21. Ryu, H., Kim, H., Choi, W., Kim, M., Park, S., Han, N., Oh, T., and Lee, J. (2006) New cold-adapted lipase from Photobacterium lipolyticum sp. nov. that is closely related to filamentous fungal lipases. Appl. Microbiol. Biotechnol. 70, 321-326.

22. Tamura, K., Dudley, J., Nei, M., and Kumar, S. (2007) MEGA4: Molecular Evolutionary Genetics Analysis (MEGA) software version 4.0. Mol. Biol. Evol. 24, 15961599.

23. Tamura, K., Nei, M., and Kumar, S. (2004) Prospects for inferring very large phylogenies by using the neighbor-joining method. Proc. Natl. Acad. Sci. U S A. 101, 11030-11035.

24. Thompson, J. D., Higgins, D. G., and Gibson, T. J. (1994) CLUSTAL W: improving the sensitivity of progressive multiple sequence alignment through sequence weighting, position-specific gap penalties and weight matrix choice. Nucleic Acids Res. 22, 4673-4680.

25. Walavalkar, G. S., and Bapat, M. M. (2002) Staphylococcus warneri BW 94--a new source of lipase. Indian J. Exp. Biol. 40, $1280-1284$.

(Received 2010.8.31/Revised 2010.10.5/Accepted 2010.10.10) 